\title{
The Special Dishes Philosophy of Sayut Ceremony in Argosari Village
}

\author{
Diana Martalia $^{1 *}$, Soenar Soekopitojo ${ }^{2}$, Titi Mutiara Kiranawati ${ }^{3}$ \\ 1,2,3 Department of Industrial Technology, State University of Malang \\ "Corresponding author E-mail: martaliadiana@ymail.com
}

\begin{abstract}
Tengger ethnic inhabiting the Argosari village and still adhere to customs and culture of their ancestors. One such firm stance is applies their sayut ceremony and serving their special dishes. The research has the objective to dig deeper into the dish identification, processing techniques, and philosophies that particular dish. This research is qualitative descriptive data results. Source of data used consist of primary sources (observation and interviews) and secondary sources (documents). Data collection techniques used such as: observation, interviews, and documentation. Data were analyzed through the steps: data collection, reduction, presentation, verification, and conclusion. The checking of findings done by cross-check data directly to the Shaman Pandhita in Argosari. The results of this study is one form of thanksgiving to the seventh month of gestation mothers and expectations regarding the baby to be born. Special dishes are served consisting of: gedhang ayu, jenang abang and jenang putih (white and red rice porridge), tamping, sisa gangga, browoh porridge, dawet, pepek (spices), tumpeng pras, tumpeng among, and treat both for the ancestors and guests. Processing techniques to make this special dishes divided into two are using and without using heat. The philosophy on this dish divided by: shape, color, meaning, and presentation.
\end{abstract}

Keywords: philosophy, sayut ceremony, special dishes

\section{INTRODUCTION}

The Tengger ethnic is a Hindu-Buddhist ethnic who live around Mount Bromo and still keeps the cultural patrimony. Reference [4] shows, they alone in modern Java are reputed to have preserved a non-islamic priestly tradition over the five centuries since the fall of Java's last major Hindu-Buddhist kingdom. Therefore, people the rest of the kingdom's fall decided to flee to areas that are difficult to reach in order to keep their beliving. One of the areas that are difficult to reach and still inhabited by tenggere thnic is Argosari Village, District Senduro, Lumajang. The village itself is well known for its tourism offering panoramic views of the peak of B29 at an altitude of 2,900 m above sea level (asl). Therefore, the rating nicknames on this tour as the "Land in the Clouds".

One form keeps the cultural values patrimony of ancestor is doing their ethnic routine lifecycle ceremony. Reference [9] shows, the ceremony is performed when an individual changes in growing and developing so that can affect the balance of his entire life. the ceremony is performed when an individual changes in growing and developing so that can affect the balance of his entire life. Therefore, this ceremony will continue to go through the whole of human life from birth, marriage, pregnancy, death, and after death.
One of the changes passed by the individual (female) is on pregnancy period near the time of birth. The ceremony was held on their individual change so its referred to as the ceremony seven months or more Tengger people known its as sayut ceremony.

Regardless of the implementation, the sayut ceremony dishes also had an philosophical and symbolic in accordance with the values in the tengger area. The dishes or culinary served at this ceremony was one of the results of culture in the form of needs, lifestyle and arts for local communities [1]. Therefore, the dish can not be found in another areas and can only be found in the Argosari village. This is caused by differences of: cultural, beliefs, natural conditions, agriculture and animal husbandry in every region in Indonesia. Reference [1] shown, culinary every area has its own differences and uniqueness that can be seen from the selection of food materials, processing methods, the traditional equipment used, and how the presentation of the food.

From some of these particularities, it could be a gold card for Indonesia to attract both local and foreign tourists. This is due to the peculiarities of culinary served can only be found in certain areas, particularly in areas still thick in culture and beliefs. Moreover, 
many people today prefer a dish that can support a healthy lifestyle and have a story behind it than just consume transform and survive alone [5]. Therefore, the selection of this dish shows that tourists are also attracted to consume slow food or certain ethnic traditional food than fast food when they make tourism. This is due to the slow food or traditional foods have cultural values that they can not find where they are and be able to support a healthy lifestyle.

One form of culinary culture that is still strong such as: a dish for sayut ceremony. These are special dishes such as food and beverages served with a specific purpose, where each dishes have a philosophy in it.

\section{METHOD}

This qualitative's study produced descriptive data such as exposure, image, and exploration of dishes sayut ceremony in Argosari Village. The technique was used consist of observation, interviews, and documentation. Therefore, the presence of the researcher in qualitative research was known as the human instrument. This human instrument had a function to set the focus of research, select informants as a source of data, collecting data and making conclusions on the findings [8].

The location of the study was conducted in Argosari Village, District Senduro, Lumajang determined purposeful. It was caused the village still not identified and well documented of ceremonial dish just like sayut ceremonies which had good potential as a cultural and culinary tourism. So, it could attract tourists to come to the village. In addition, the village lied at an altitude of $2,900 \mathrm{~m}$ above sea greatly influence the selection of the study sites. It was caused a place that Tengger people stayed in higher place was had more viscous culture that the lowest one.

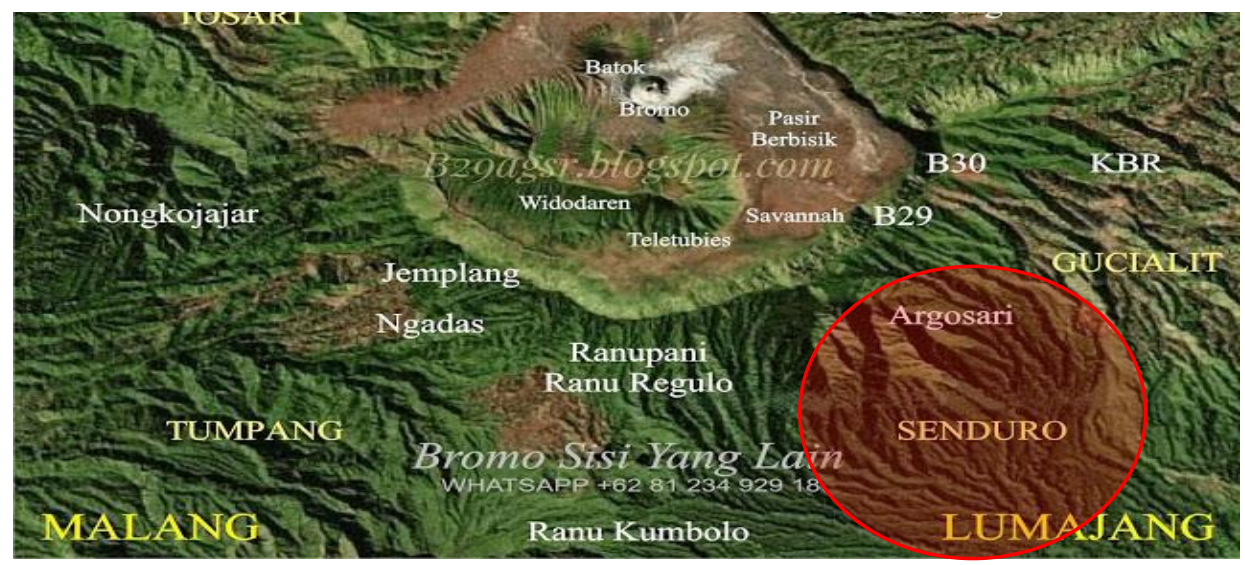

Figure 1. Location of research: Argosari Village

The data source on qualitative study was consist of: primary sources just like direct observation and in depth interviews with the native community and also secondary source through related documents. To gather these sources, data collection techniques were used moderate participatory observation, semi-structured interviews, and documentation. In depth interviews were conducted directly to: (1) Mr. Kariyoleh (KY) as Shaman Pandhita in the village who knew: the sequence of the ceremony especially sayut ceremony, what dishes are presented, how to made it, until the dishes philosophical; (2) Mr. Sukarto (SK) as one of the Pemangku in the village who helped some specific ceremonies; (3) Mr. Buana (BN) as one of his relatives Shaman Pandhita which is his place often used as a place to make dandanan (offering); and (4) Mr. Wido (WD) as one of the candidates young shaman in the village.

Data analysis was performed by: collecting data, reducing the data, presenting data, data verification, and conclusion. Checking the validity of the findings was cross-checked by direct interview to $\mathrm{Mr}$. Kariyoleh as Shaman Pandhita. The research phase needed to be done consists of: planning, implementation, and report writing.

\section{RESULTS AND DISCUSSION Sayut Ceremony}

Sayut (javaness called it tingkeban) is a ceremony of seven monthly cerebrated by Tengger ethnic. At this ceremony, there are some traditions which are: (1) catch the chicken, (2) bathing (siraman) with garden's flower water, (3) break up the coconut or eggs, and (4) selling rujak or dawet. First, tradition to catch the chicken was done by the baby's father. Live chickens that had previously been prepared was placed in Tanggi (traditional steamer basket made of woven bamboo), wherein the hole of the tanggi adjusted to the size of a chicken's head. Chickens was placed within this tanggi assisted by Shaman Baby to be issued and released, then the baby's father who had a duty to arrest and put it in a cage.

"Before the mother was bathed (siraman) by garden's flower water, this live chickens will be released and 
Second, bathing (siraman) tradition was done to seventh month of gestation mother using garden's flower water. According to Shaman Pandhita explained that, "kembang (flower) used to siraman consists of a wide variety of fragrant flowers and there was in their garden who had this ceremony". He also said that, "if their garden had not fragrant flowers, they would buy it on the market with a wide range of existing fragrant flowers, such as magnolia flower, rose, jasmine, and etc". This tradition was also one performed for celebrating the seventh month pregnancy. Here was the documentation of bathing with garden's flower water (siraman) and cracking the coconut.
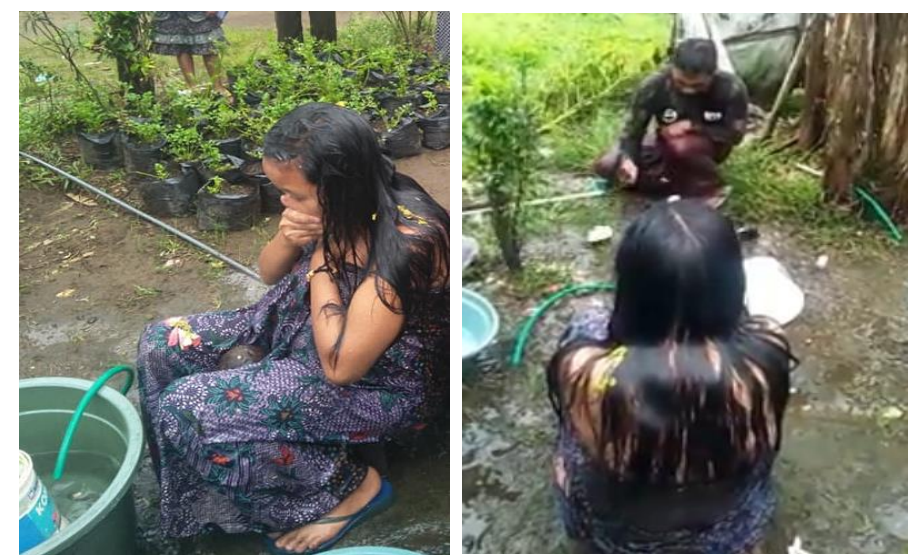

Figure 2. (a) The Siraman Procession and (b) The Procession of Cracked Coconut

The statement was supported by the Shaman Pandhita in Argosari village.

"The flowers's philosophy used in this siraman tradition is as a symbol of pleasure, joy. The purpose and objectives of this siraman tradition of which was that the baby who was celebrated at seven months gestation at its mom belly could be Suputra child. Children who suputra means that the child is expected to always bring joy to parents, relatives, and friends. That was the meaning of this splash ceremony."

The statement was supported by WD statement.

"The mother who had worn jarik and bathed with kembang's water (flower). Siraman (bathe) the baby's mother performed alternately by the family, such as fathermother from baby's mother, fathers-mother from baby's father, and their relative. In this siraman should also be an odd number. Either that, one of the family splashed 1 times or up to 3 times. In this siraman also not haphazardly done, the family had to pour these flower's water to baby's mother with the direction from the back to the fore. Siraman itself has meaning to expedite the delivery process of the baby's mother."

In addition to the siraman procession, at this ceremony there was also a ceremonial procession to cracked the coconut or eggs and selling rujak and dawet. According to the results of an interview with Shaman Pandhita in Argosari village explained as follows.

"In here, Rujak and dawet is a symbol of love. The rujak of fruit made from apples, papaya, watermelon, guava, pineapple, star fruit, bengkuang, cucumber and peanut sauce. This peanut sauce also made of fried peanuts, brown sugar, and water that was mashed by a stone mortar and pestle. Dawet that was used in this ceremonial had red colour. It was different with the dawet which ussualy we meet"

Meanwhile, according to an interview with one of the residents in Argosari village said that, the procession of coconut's cracked conducted by the baby's father, whereas for selling rujak and dawet done by baby's mother. This explanation was supported by the statement of WD.

"At the time of coconut or eggs solve this is done by the baby's father. Cracking the coconut or eggs have the sense that the child will not born sara. As for sales that the baby's mother do, she will sell rujak (especially rujak of fruit) and dawet. For both of these foods (rujak of fruit and dawet) can be purchased or prepared beforehand, so the baby's mother staying sell it." 
In the implementation of this sayut ceremony was not arbitrary, which was done when the baby's mother enter pregnancy seven months and should not be missed. On the implementation of this ceremony would also need to contain elements of the number seven, for example date: 7, 17, or 27. Dress or offerings, offerings for the Tengger community designation, which need to be prepared for this ceremony was: gedhang ayu, jenang abang and jenang putih (red and white porridge), tamping, pepek (spices), pras, among, rice, side dishes, drinks, and snacks (in the form of snacks telesan and garingan). In addition to the dandanan, there was also a browoh porridge made from rice flour that was boiled to form a slurry. The statement was supported by the Shaman Pandhita in Argosari village.

"Pregnancy ceremony in here was known by the name of sayut. Sayut had meaning was seven months (javaness called it tingkeban). Here, the ceremony was held at seven months gestation entry and held on the dates associated with the number seven, such as 7 , 17, and 27. In addition, the ceremony also served porridge, browoh porridge. This porridge was available on sayut ceremony only. The philosophy of the browoh porridge is cikal bakal (the genesis of the seed). This porridge made from rice flour that was boiled to form a slurry"

\section{Sayut Dishes}

The word dish itself come from a word that means serving. Reference [2] said that the dish is something that is presented or disclosed to someone in the form of food, drinks, and so on. Meanwhile, reference [6] said that something which is presented can be categorized into: main dishes, side dishes (both animal and vegetable), vegetables, sauces, snacks, and drinks. Of the six classifications of those dish, there are four that can be founding on the sayut ceremony. However, of the four classifications, there are some additional offerings that are not using heat just like gedhang (consist of banana, banana leaf, betel leaf, jambe leaf, and whiting), and flower for sisa gangga (consist of plawa flower, edelweiss flower, and kenikir flower).

\section{Special Dishes or Dandanan}

Dandanan or offerings have various classifications and types. According to WD explained that, "all of this (dandanan) has its own meaning and their is none of which should be added or reduced". Therefore, there were materials difficult to find in that area to be used in making those dandanan. These ingredients like a: uncooked white rice and red rice, chicken and so on. The dandanan made of various materials was arranged in such a way, prayed, and part of it which was eating and partly throw away. Reference [3] said that, one tangible form of teaching embodies about deep gratitude and gratefulness is to send prayers to God Almighty and to ancestral spirits accompanied by selamatan or making sesaji.

He also said that the sesaji made is only used as a form of almsgiving or giving thanks to all of God's creations. This was also found in this study that the researcher found some dandanan served to be eaten individually and thrown away afterwards. For these discarded dandanan, some of which exists the tamping or gangga remnants to be presented to the spirits of the watchman or Dewata (Gods). This is in accordance with the opinion of [7] stating that the traditional ceremonies generally aim to honor, be grateful, worship, ask for salvation from God through spirits and their ancestors. This is because this traditional or customary ceremony is used as an activity expected to connect humans with the "upper world" (God Almighty). Dandanan or offerings can be categorized into two that are necessary and need not using a heat, the following explanation.

One special dandanan in this ceremony is browoh porridge, rujak of fruit and dawet. Besides that special food, there was another dandanan that made in this ceremony. In this dandanan, generally there was a tumpeng (cone- shaped rice decoration) with white rice and cone-shaped formation called tumpeng pras. According to the local community, this tumpeng has several philosophies namely: (1) the word pras in this tumpeng has a meaning of ngepras kala-kala (slam of bad behaviour of human beings); (2) the cone-shape of the tumpeng symbolizes a father or a male; and (3) the white color on the contents of tumpeng (rice) symbolizes the purity. To make this tumpeng, the Tengger ethnic community needs to coat the print with banana leaves and get this tumpeng printed. The coating of banana leaves also has a meaning for the Tengger ethnic, which symbolizes the notion that human beings are not barely naked in life a anchor (evil) people.

Almost similar to the dandanan pras, the dandanan among is also found at the sayut ceremony. According to the local community, this tumpeng has several philosophies such as: (1) derived from the word among which means ngamongi or keeping people alive (people who are hailed) every day and wherever they go; (2) the shape of a semi-circle tumpeng symbolizes the mother; (3) the white color of the rice symbolizes the purity, and (4) the wrapping of tumpeng among in the form of a banana leaf symbolizes that human beings are not barely naked. 

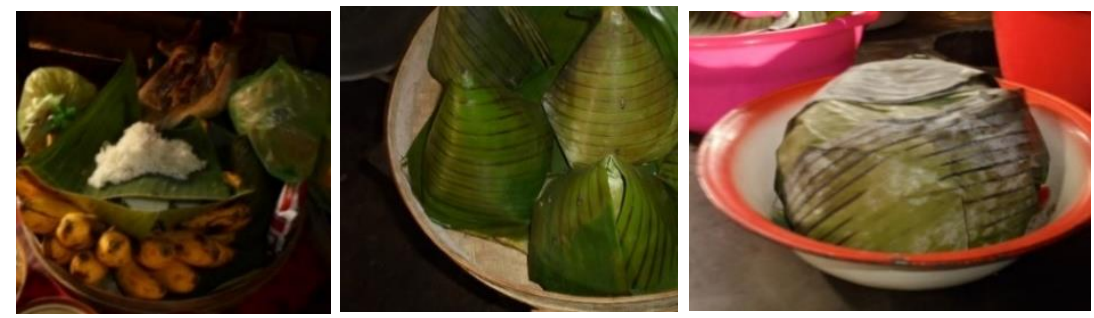

Figure 3. Left Dress Pras and Among, Central Tumpeng Pras, and Right Tumpeng Among

Both these dandanan pras and among generally have the same content made up in the receptacle, which includes: (1) tumpeng pras or tumpeng among; (2) gedhang ayu which is as a whole has a meaning as a place of ancestral to linggih (seat) and contains: two bananas cloves, meaning the harmony of life, kinangan consists of betel, njet or whiting, and jambe or areca nut, as a whole has the meaning that humans are created, maintained, and eventually they will get dissolved or die; (3) banana leaf as a barrier means that humans are not barely naked; (4) sticky rice placed on telesan snacks has meaning as an adhesive or reminder that the descendants did not forget their ancestors; (5) ingkung chicken, in the form of a kampung chicken that has been cleaned and burned to dry has a meaning as a symbol of sacrifice and had a form look like it's bowing down that symbolize silence; (6) one pack of instant noodles as a substitute for fallow or spreading plants with the characteristic of excitement and has the meaning that in this life there must be an intermediary or connecting agent of excitement; and (7) jajanan telesan (in the form of juadah, pépés, pasung) and jajanan garingan (such as matari and rengginang) have their respective meanings as rainy and hot or dry seasons.
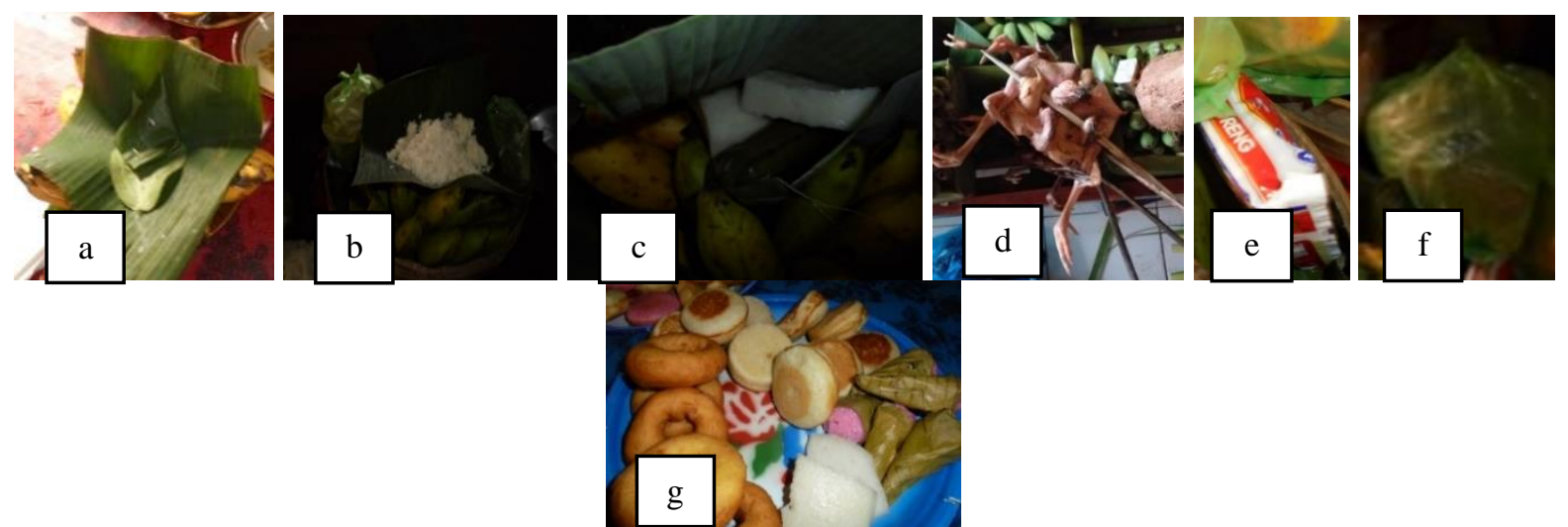

Figure 4. Special course in Makeup: (a) Gedhang Ayu; (B) the sticky rice covered with banana leaves; (C) snacks telesan that are placed under glutinous rice; (D) the chicken ingkung; (E) replacement fallow including instant noodles; (F) a variety of snacks telesan; and (g) garingan snacks.

From the various jajanan served, some jajanan must be present and having their own philosophies, some of which are: pépés, juadah, and pasung. First, pépés itself is a jajanan which resembles the nagasari. According to the local community, both nagasari and Pépés doughs are similarly made from rice flour, liquid coconut milk, grated coconut, water, and filled with bananas. However, there are differences in shape, that the nagasari is rather more rounded while Pépés is more rectangular. The philosophy contained in this pépés is that: (1) wrapped in banana leaves which symbolizes that human beings are not barely naked; (2) the rectangular shape which symbolizes the direction of the compass (east, south, west and north); and (3) white-colored contents which symbolize the purity.
Second, juadah is a traditional Tengger ethnic dish that resembles a tetelan, but has a finer or smoother texture. Similar to Pépés, Juadah also has the same philosophy. The ingredients of this dish include: rice flour, corn flour, grated coconut, and coconut milk. Third, pasung is a dish that has exactly the same mixture as apem dough which will be steamed later. Making the pasung include: ingredients consisting of rice flour, sugar, grated coconut, and cassava tape blended then mixed and arranged into a banana leaf shape to form conical, and pinned with biting and finally steamed. The philosophy of pasung consists of: (1) wrapped in banana leaves which symbolizes that human beings are not barely naked and (2) in the form of a contong (funnel) symbolizing a father or a male. 

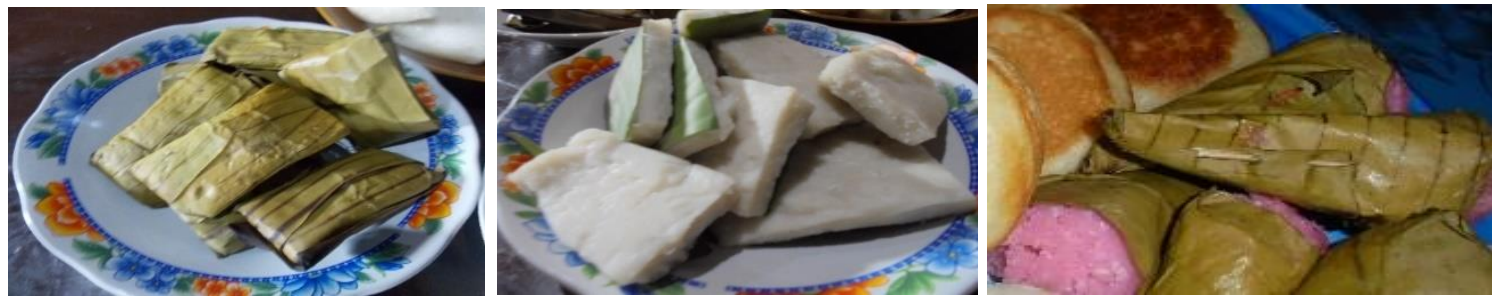

Figure 5. Snacks Telesan Must be There: Left Pepes, Central Juadah and airborne Right

Tamping and ganggan remnants is one of the dishes wrapped in banana leaves and placed in a rice bowl, always served in a life cycle ceremony and later discarded or presented to the guardian spirit or intermediary (near the door and fire) or to the God of Water (specifically for water called the ganggan remnants). The difference of tamping and the gangga remnants can be seen from the three types of flowers served for the gangga remnants. These three types of flowers include: (1) edelweiss (symbolizing immortality), (2) senikir (symbolizing sincerity), and (3) plawah (symbolizing peace).
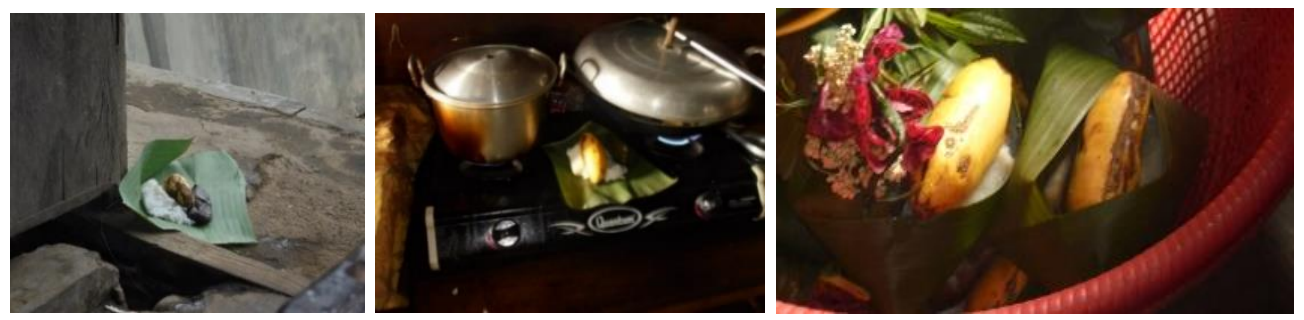

Figure 6. Tamping and the Rest of the Ganges: Left Tamping at Entrance, Central Tamping near the Fire, and the Right Tamping and Remaining Ganggan in Tanggok's Rice

Jenang abang or jenang putih are dishes that need to be included in every Tengger ethnic life cycle ceremony in Argosari Village. This is because according to the local community if there is no jenang abang or jenang putih, then still can not be called a slametan. Pepek seasoning or pencok of nut is a dish in a takir consisting of various herbs such as: peanuts, green beans, onions, garlic, chili, galangal, and so forth. This pepek spice symbolizes the bitterness of life. Treat for ancestors in the form of white rice (a symbol of purity seen from its color), side dishes (symbol of sacrifice) in a plate, and drinks in a glass (after serving food should be served with drinks too) presented to the ancestors as a symbol of gratitude or gratefulness. In this case, the treat is generally almost similar as what is provided for the guests but for these ancestors just in a little one plate only.
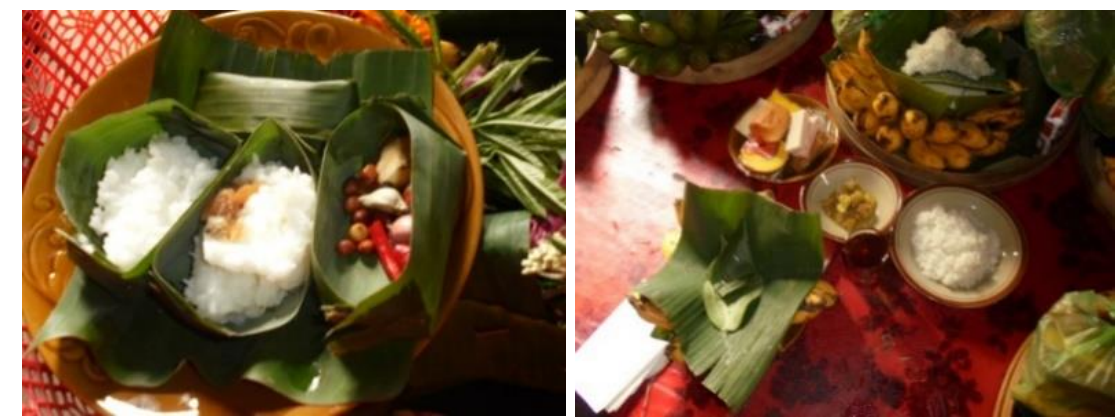

Figure 7. Left Dress Kekerik (Jenang Abang, Jenang White and Seasonings Pepek), Right Treat for Ancestors 


\section{Dishes for Guest}

In addition to dishes used for dandanan, the Tengger ethnic life cycle ceremony in Argosari Village also has dishes particularly served to guests. The dishes served at each host of the life cycle ceremony are generally different because they are no specific requirement for serving to guests. This causes the dishes served to guests are adapted to the ability of the host by using ingredients which are easily found in the area, such as wrecis (ercis, such as peas), benguk (koro beans), ucet (beans).

The dishes served for ancestors and guests include: rice, various kinds of side dishes cooked with various processing techniques, jajanan (telesan and garingan), fruits (such as: bananas), and hot drinks in the form of tea, wedang ireng (black coffee), and wedhang putih (sugar water). Meanwhile, of the three types of drinks served, there are hot tea and hot coffee to allow guests
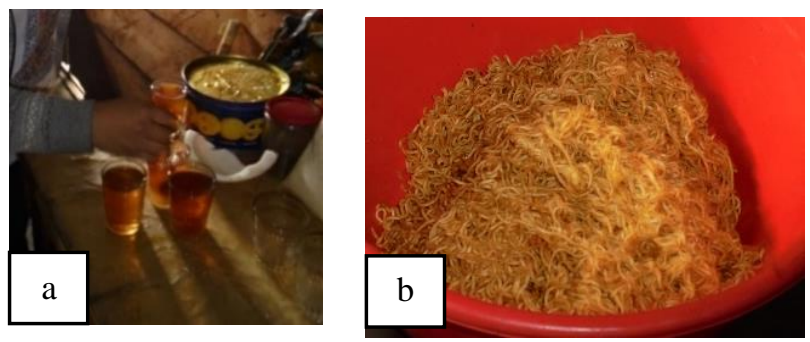

maintain their body temperature in the highland environment. Specifically, the contents of tumpeng pras and tumpeng among is made from rice and cooked by means of karu (a technique to cook rice with steaming and pouring hot water until cooked rice). In addition to rice, sticky rice (cooked) is also made from the raw sticky rice which is through the process of karu.

According to the local community, the method of making cooked rice or sticky rice consists of: (1) heating water in a separate containers (Tengger ethnic community in Argosari Village using kettles (ceret)) to meet the boiling, (2) putting raw rice into the pot and steaming it until half cooked, (3) then flushing the cooked rice with hot water that has been prepared beforehand, (4) the cormorant is closed and until welll-done cooked.

Figure 8. Treat for Guest: (a) Hot Tea; (B) Mie Goreng as One of the Side Dishes; (c) as One of the Boiled Eggs Side Dishes; (d) the Fruit and some Snacks

\section{CONCLUSION}

Special dishes ethnic Tengger at the sayut ceremony in Argosari Village is one form of thanksgiving to the seventh month of gestation mothers and expectations regarding the baby to be born. Special dishes are served consisting of: gedhang ayu, jenang abang and jenang putih (white and red rice porridge), tamping, sisa gangga, browoh porridge, dawet, pepek (spices), tumpeng pras, tumpeng among, and treat both for the ancestors and guests.

Processing techniques to make this special dishes divided into two are using and without using heat. First, the special dishes or offerings that are not using heat just like: gedhang (consist of banana, banana leaf, betel leaf, jambe leaf, and whiting) and flower for sisa gangga (consist of plawa flower, edelweiss flower, and kenikir flower). The other one is dishes that using heat to cooking are (a) jajanan (steaming, boiling, frying, etc); (b) cooked rice and sticky rice (dikaru means steaming and boiling), (c) ingkung chicken (burn on the coal); (d) red, white and browoh porridges (boiling), (e) Tengger drinks like hot tea and hot coffee (boiling, so they can maintaining their body temperature) and also (f) tengger dishes with their various techniques of processing (dishes for guest).

The philosophy on this dish divided by: shape, colour, meaning, and presentation. First, shape of offerings that are found comprising: (a) rectangular at both Pepes and juadah's form emblem direction of the wind; (b) semi-circle at tumpeng among symbolizes of mother; (c) triangle at tumpeng pras pangresikan symbolizes male, (d) chicken ingkung bowing down position symbolize silence. Second, colour on offerings that are found comprising: (a) white in the rice, sticy rice, jenang putih, and browoh porridge symbolize purity; (b) white in the edelweiss flower at sisa gangga symbolized of eternity; (c) red in jenang abang symbolize of courage; (d) red in plawah at sisa gangga symbolize of peace; (e) and yellow in Kenikir at sisa ganges symbolize of sincerity. Third, meaning of a dish that are found devided into: (a) Name, like pras, among, and so forth); (b) posision like: the sticky rice layed on jajanan telesan have meaning the nature of the sticky sticky so that the descendants as adhesive it does not forget their ancestors); (c) meaning itself, like a whole gedhang ayu which is as a whole has a meaning as a place of ancestral to linggih (seat) and contains: two bananas cloves, meaning the harmony of life, kinangan consists of betel, njet or whiting, and jambe or areca nut, as a whole has the meaning that humans are created, maintained, and eventually they will get dissolved or die; ingkung chicken, in the form of a kampung chicken that has been cleaned and burned to dry has a meaning as a symbol of sacrifice; one pack of instant noodles as a 
[3] Giri MC, Wahyana. (2010). Sajen and Ritual Javanese. Yogyakarta: Narrative.

substitute for fallow or spreading plants with the characteristic of excitement and has the meaning that in this life there must be an intermediary or connecting agent of excitement; jajanan telesan (in the form of juadah, pépés, pasung) and jajanan garingan (such as matari and rengginang) have their respective meanings as rainy and hot or dry seasons; browoh porridge has the meaning that is the genesis of the seed; and rujak of fruit and dawet has a meaning as a symbol of love. Forth, the special dishes's presentation that are found comprising: (a) wrapped or covered with banana leaves means man was not naked, and (b) the special dishes's laying at in different places that do not have a philosophy, but it is done for grouping only.

\section{REFERENCES}

[1] Ariani, RP (2017). Bali Culinary Know. Depok: PT. King Grafindo Persada.

[2] Language Development and Cultivation Agency. (2016). Indonesian Dictionary Fifth Edition. Jakarta: Ministry of Education and Culture of the Republic of Indonesia.
[4] Hefner, Robert W. 1989. Hindu Javanese: Tengger Tradition and Islam. New Jersey: Princeton University Press.

[5] Kwon, Dae Young. 2015 What Is Ethnic Food. Journal of Ethnic Foods. [Online]. 2(1), pp.1. Available https://www.sciencedirect.com/science/article/ pii/S2352618115000025.

[6] Nurani, Dra. A.S. \& Lasmanawati, Dra. Elly. 2016. Food Processing and Presentation (Module 4) [Online]. Available: http://ppg.spada.ristekdikti.go.id/course/view. php?id=70

[7] Rostianti, Ani., Susilantini, Endah., Sumarsih BA, Sri., Wibowo. (1995). Traditional Ceremony Function for People for the Present. Yogyakarta: Ministry of Education and Culture.

[8] Sugiyono. (2013). Understanding Qualitative Research. Bandung: Alfabeta.

[9] Yulianti, Yayuk. (2013). Tengger Women's Role in Environmental Management. Malang: Single Independent Publishin 